Article

\title{
Types of Green Innovations: Ways of Implementation in a Non-Green Industry
}

\author{
Francesco Calza, Adele Parmentola and Ilaria Tutore * \\ Dipartimento Di Studi Aziendali E Quantitativi, University of Naples “Parthenope”, 80132 Naples, Italy; \\ francesco.calza@uniparthenope.it (F.C.); adele.parmentola@uniparthenope.it (A.P.) \\ * Correspondence: ilaria.tutore@uniparthenope.it; Tel.: +39-081-547-4113
}

Received: 12 July 2017; Accepted: 20 July 2017; Published: 26 July 2017

\begin{abstract}
Attention to environmental sustainability represents an essential issue for the companies that, in order to integrate environment into their strategies, are producing specific innovations that have also positive environmental outcomes. Implementing green innovations represents a great challenge for non-green companies because it often requires the acquisition of new resources and competences that differ significantly from their existing competences. This paper attempts to propose a theoretical framework that classifies green innovations according their impact on company's competences and analyses how green innovations can be implemented. Given the complexity of the issue and the variability of situations, we use a multiple case study analysis of several green innovations developed in a non-green industry, namely the automotive sector. Indeed, this is one that produces the highest environmental impact and, in recent years, it has been subjected to increasing regulatory restrictions. Companies operating in a non-green industry that implement disruptive, radical and architectural green innovations can initiate market and technological partnerships to mitigate against such internal weaknesses, such as the lack of technological capabilities and market knowledge. The collaboration helps firms to access new competences and capabilities useful to change or develop new technology capabilities and market knowledge more easily and with lower costs.
\end{abstract}

Keywords: green innovation; collaboration; partnership; automotive industry

\section{Introduction}

Attention to environmental sustainability today represents an essential issue for the companies working in non-green industries also.

Companies are changing their attitudes not only because they are forced by national and international laws or by the pressure from consumers but also because the adoption of environmental management strategies creates opportunities for business organizations.

Previous studies on the topic demonstrated that environmental management of firms may strengthen their economic goals [1]. Even if environmental management may not perhaps increase profitability in the short term, it could create economic payoffs in the long term [2].

In order to "go green", companies are finding several methods and practice to deal with environmental issues.

One of the ways through which companies incorporate environmental issues into their strategies while reinforcing their competitive advantage is through innovations that can have positive environmental effects. Indeed, it has been demonstrated that the performances of green innovations, both as products or processes, are positively correlated to corporate competitive advantage [3].

Green innovation-defined as "innovations that consist of new or modified processes, practices, systems and products which benefit the environment and contribute to environmental sustainability" ([4], p. 567)—can lead to the reduction of inefficiencies and the rational use of natural 
resources, constituting an important source of cost reduction. On the other hand, considering increased consumer awareness on the environmental impact of consumption choices, the environmental attributes of new products and services $[5,6]$ can be used for marketing differentiation.

The attention of green innovation management is becoming a hot topic both in practice and in academia [7].

A great part of these studies has tested the linkage between this type of innovation and firm performance $[8,9]$. Other studies have focused on the specific determinants of green innovation at the firm level, specially paying attention to the role of internal factors (technology push), external factors (market pull) and/or environmental regulation (regulation push/pull) [10-12].

Particularly in the innovation management field, we are aware of only few scholars who conduct research dedicated to new product/service development of green innovations. Nevertheless, implementing green innovations represents an important challenge for non-green companies that want to achieve environmental improvements taking into account their competitiveness, because it often requires the acquisition of new resources and competences that differ significantly from their existing competences.

Previous studies on green innovations have often neglected this latter aspect because they have generally been focused on defining the specific features that distinguish green innovations from generic ones, on the effect of environmental policies, on fostering these innovation activities, or on the drivers of green innovations and its effect on firms' competitiveness. Thus, to the best of our knowledge, the majority of the studies have focused attention on "who" has pushed green innovations, and "why" they occur and with which results, without noting "how" they are developed.

Moreover, despite several classifications of green innovations that have been provided, none of them relate the types of innovation to companies' efforts to develop them.

To fill this literature gap, our paper is aimed at answering the following question:

RQ (Research Question). How can the different kinds of green innovations be developed by companies operating in non-green industries?

This paper attempts to contribute to the studies on this topic by proposing a theoretical framework that classifies green innovations considering the impact of these innovations on a company's resources and competences and analyses how green innovations can be implemented. In particular, we focus on green innovations developed in non-green industries, where innovation development lies far from the company's core business and current resources and capabilities.

To identify the different types of green innovations according to their fit with existing market or technical capabilities, we use the "Innovation Landscape Map" of Pisano [13].

Then, we have employed a multiple case study analysis to identify how automotive companies have implemented different kinds of green innovations.

This paper is structured as follows. The next section presents the theoretical background of the studies that specifically relate to green innovation. Section 2 presents the research design, including a brief overview of the units of analysis, data selection and collection. The fourth section discusses the findings of the empirical analysis of green innovation in the automotive industry. The final section presents our main conclusions, implications and limitations of the paper.

\section{Theoretical Background}

Green innovations help companies insert environmental issues into their strategies in order to create or consolidate their competitive advantage.

Numerous empirical findings confirm a positive relationship between green innovation and firm performance [14]. Green innovation is closely associated with corporate environmental management and eco-target achievement; therefore, green innovation is widely believed to stimulate environmental performance [3,15]. Green product and process innovation not only reduce negative environmental impact, but they also increase the economic and social performance of a company through waste and 
cost reduction [16]. Companies implement green process innovation in the manufacturing process to shorten production time and reduce costs [17]. In addition, a good product innovation improves market position, affirms brand names, leapfrogs competition, creates breakthroughs, and attracts new customers [18]. The literature on the topic employs different terms to refer to green innovation; words like eco-innovation, environmental innovation, eco-technologies, and green technologies are used indistinctly because they are related to the same topic and can be used largely interchangeably [7]. A number of definitions exist for the notion of green innovation. One of the first, by Fussler and James [19] defines eco-innovations as "new products and processes which provide customer and business value but significantly decrease environmental impacts". In a similar manner, Kemp and Pearson ([20], p. 3) define eco-innovation as "the production, assimilation or exploitation of a product, production process, service or management or business method that is novel to the organization and which results, throughout its life cycle, in a reduction of environmental risk, pollution and other negative impacts of resources use (including energy use) compared to relevant alternatives". Driessen and Hillebrand ([21], p. 344) apply "a rather pragmatic definition", stating that it "does not have to be developed with the goal of reducing the environmental burden. ( . . ) It does however, yield significant environmental benefits". Chen et al. ([3], p. 534) define green innovation "as hardware or software innovation that is related to green products or processes, including the innovation in technologies that are involved in energy-saving, pollution-prevention, waste recycling, green product designs, or corporate environmental management".

In comparison to the eco-innovation definitions, Oltra and Saint Jean ([4], p. 567) define green innovation "as innovations that consist of new or modified processes, practices, systems and products which benefit the environment and so contribute to environmental sustainability".

This definition includes all the changes in the product portfolio or in the production processes that help to reach environmental targets and consider the effect of the innovation activities without taking into account the initial intent, including both incremental and radical improvements [22].

After a detailed literature on the topic, Schiederig et al. [7] identified six important aspects in the different definitions of this kind of innovation:

(1) Innovation object: Product, process, service, method;

(2) Market orientation: Satisfy needs/be competitive on the market;

(3) Environmental aspect: Reduce negative impact (optimum = zero impact);

(4) Phase: Full life cycle must be considered (for material flow reduction);

(5) Impulse: Intention for reduction may be economical or ecological; and

(6) Level: Setting a new innovation/green standard to the firm.

These innovations can occur not just in green industry, namely sectors in which the environmental protection represents the main firm's core business, such as recycling material, generating and storing renewable energy or natural product manufacturing companies, but also in companies situated in traditionally non-green industries or with a product portfolio filled with goods that are not green.

Green innovations may be technological or non-technological (organizational, institutional or marketing-based) and can be driven by economic or environmental influences based on the need to balance shareholder and stakeholder interests.

Previous studies on green innovation have generally focused on their specific peculiarities, as well as their drivers and barriers.

In particular, scholars question whether green innovations differ from the other kinds of innovations and therefore whether a specific theoretical and political interpretation is needed [22].

Green innovation differs from standard innovation for at least for two different motivations: the specific externalities they are able to procure and the specific drivers at the basis of their development.

Regarding the first point, Rennings [12] suggests that environmental innovations produce "double externality problems". The first is the knowledge spillovers generated that benefit other firms, reducing the incentive for firms to invest in them, as they cannot fully appropriate the value created. 
In addition to this kind of negative externality, green innovation also results in positive environmental externalities: the value created by cleaner technologies can be appropriated by the entire society [22].

Moreover, companies that invest in green technologies sustain higher costs that can reduce incentives to invest in such activities [12,23].

The second peculiarity of green innovation is the considerable role played by policy interventions to drive its introduction [12]. Indeed, while general innovation envisages demand-pull and technology push factors, the determinants of green innovations are primarily induced by regulation.

This consideration is line with the so-called Porter's hypothesis: it postulates that well designed environmental requirements enhance corporate competitiveness [6] and "trigger innovation that may partially or more than fully offset the costs of complying with them" ([6], p. 98).

Other studies on green innovation determinants $[10,24]$ confirm that regulation and cost savings cover a critical role into pushing eco-innovation, even if green innovation today is proactively driven by entrepreneurial and intrapreneurial initiatives.

Furthermore, these studies suggest that, with respect to general innovation, these activities require more external sources of knowledge and information.

Recent analysis on antecedents on these innovations recognizes the internal companies' features as important drivers of green change.

In particular, in terms of organizational factors, authors identified intra-organizational collaborations [25], green core competences [26], green shared vision, green absorptive capacity, and green organizational ambidexterity as additional drivers of green innovation [27].

Several works have also demonstrated that green innovation practices affect not only environmental performance but also firm performance [28,29] since green innovation should be seen not only as reactive fulfillment of government requests but as a proactive practice to gain a competitive advantage and improve business performance.

Nevertheless, green innovations are not all the same. Different kinds of green innovation require different kinds of resources and competences and consequently imply different implementation modes.

Studies on the topic tried to provide convergent classification of green innovations. Kemp and Pearson [20] identify four different eco-innovations, according to the specific nature of the innovation, namely the "environmental technologies" as pollution control technologies i.e., waste water treatment technologies, cleaner process technologies or green energy technologies; "organizational innovation for the environment" as the introduction of organizational methods and management systems for dealing with environmental issues in production and products; "product and service innovation offering environmental benefits" which are new or environmentally improved products and environmentally beneficial services, and "green system innovations" which are alternative systems of production and consumption that are more environmentally benign than existing systems. Another relevant classification of green innovation employed in literature is provided by the EU Community Innovation Survey (CIS).

The CIS envisages six types of green innovations that refer to environmental benefits deriving from the production of goods or services: reduced material use per unit of output; reduced energy use per unit of output; reduced $\mathrm{CO}_{2}$ footprint (total $\mathrm{CO}_{2}$ production); replaced materials with less polluting or hazardous substitutes; reduced soil, water, noise, or air pollution; and recycled waste, water, or materials [20]. The other three green innovations (GIs) are related to the benefits deriving from the after-sales use of a good or service: reduced energy use; reduced air, water, soil or noise pollution; improved recycling of product after use [20].

The aforementioned classifications have only an external focus. On the contrary, adopting an internal focus, Chen et al. [30] provided a classification of green innovations according to firms' attitude toward environmental problem. Authors distinguished between "proactive green innovation" as new practices or products ahead of competitors, to decrease cost, to seize opportunities, to lead in the market, or to obtain competitive advantages and "reactive green innovation" related to firms' passive 
behavior, developed to comply with environmental regulations, to adapt to stakeholders' requests, to react on the changing environment, or to respond to competitors' challenges.

They empirically demonstrated that proactive green innovations are mainly pushed by internal firms' features, such environmental leadership, environmental culture, and environmental capability, while reactive green innovations are more related to environmental regulations and stakeholders' expectations.

Despite this latter classification providing an internal focus of green innovation, it takes into account the firms' attitude towards environmental engagement rather than exploring how green innovation can be implemented by different companies.

Thus, there is a need of a classification method that measures the impact of green innovations on the implementing firms with respect to the way they decide to invest in these kinds of innovation activities.

In order to fill this literature gap and evaluate how companies can generate green innovations, in this paper we develop a wide taxonomy of green innovation employing the "The Innovation Landscape Map" elaborated by Pisano [13] for generic innovations (Figure 1).



Figure 1. The Green Innovation Landscape Map. Source: Our elaboration of Pisano [13]. GI: green innovation.

Since we want to investigate green innovation in the non-green industry, this map allows us identify the different typology of green innovations according to their fit with existing market or technical capabilities.

The map is built on the assumption that companies must choose how much of effort to focus and invest in technological and business model innovation.

The map presents innovation characterized along two dimensions: the degree to which it involves a change in technology, and the degree to which it involves a change in business model [13].

When an innovation strategy leverages an existing business model and hence its customer base or technical competencies, a company employs current resources and capabilities and thus preserves its value chain to develop its innovation.

In contrast, when a potential innovation fits less with a company's existing business model and technical capabilities, the company should consider how to invest and develop new resources and capabilities suffering higher risks.

When a new business model is created, a company should consider revising its entire value chain and industry network to accommodate product and market changes. 
Thus, the model is particularly useful for explaining green innovations in non-green industries because companies working in non-green sectors need to invest considerable resources to change both their technology and business models to implement a truly green innovation since the formation of eco-systems and networked organizations becomes critical in forging environmental sustainability.

Despite the fact that both dimensions represent a continuum, Pisano [13] identifies four quadrants, or categories, of innovation. The routine green innovation (quadrant I) is built on a company's existing technical capabilities and is coherent with its existing business model-and hence its market base.

A company develops a disruptive green innovation (quadrant II) when it requires a new business model even if the technological breakthrough is not needed. These innovations are able to disrupt also the business models of other companies, representing a real challenge for the companies that operate in the same competitive area.

In the third quadrant, the challenge is purely technological: radical innovation is the opposite of disruptive innovation and is developed with new technical competences maintaining the existing business model. The last typology is the architectural green innovation, which combines technological and business model disruptions.

Considering the different impact of different innovation types on companies' resources and capabilities and the different efforts required by different kinds of innovations, we used the green innovation landscape map to analyze the different sources of innovation development starting from the idea that a company's green innovation strategy should determine how the different typology of innovation fit into the company's strategy and the resources that should be allocated to each [13].

To understand the specific process at the base of green innovation development we identify four green innovations that have flourished in the automotive industry.

\section{Methodology}

Given the complexity of the issue and the variability of situations, we use a multiple case study analysis of several green innovations developed in a non-green industry. Since the purpose of the theoretical case-based research is to develop theory, rather than to test it, theoretical sampling is considered more appropriated than random or stratified sampling [31].

We can find the basis of this methodology in Yin [32], who outlines a roadmap for the construction and development of theories based on case studies.

Case-studies analyses allow us to obtain better knowledge and a deep understanding of a complex problem and represent the most suitable methodology when themes and patterns need to be identified rather than confirmed [31,33].

In order to answer to our main research questions and identify how the different kinds of green innovations can be developed, we decide to focus the attention on automotive industry.

Among others, automotive activities affect humans and the natural environment to a very great extent.

This is one of the industries that produce the highest environmental impact and, in recent years, it has been subjected to increasing regulatory restrictions.

Automotive is a highly dynamic, competitive, global and innovative industry that has made remarkable contributions to the world economy and people's mobility, but its products and processes are significant sources of environmental impact [34].

The most important drivers of innovation in car industry are consumer demand (in terms of better performance, comfort, safety and fuel consumption), international competition and environmental targets [35].

In the automotive sector the question of greening the automotive industry no longer has a "yes or no" answer. The debate has moved on from "why" to "how" and "by when", such that the greening innovations support other business conditions including profitability, customer satisfaction, product safety, and reliability" [36]. The rise in environmental commitment in automotive industry is even more relevant after the Volkswagen scandal in USA, around the use of cheat software to fool testers. In 
the past, most automotive companies considered environmental compliance an additional production cost instead of considering it a fundamental process to prevent negative environmental impacts. However, strict environmental regulations and environmentalists have changed the competitive rules and patterns for companies. The increasing costs of traditional modes of compliance and advances in material and process technologies have driven some automotive supply chain companies to adopt green innovative approaches to overcome environmental challenges [37].

Despite recent efforts to convert and adapt automotive activities to green requirements, the sector cannot be considered as a green industry, since green innovation is not properly related to automotive companies' core business.

Nevertheless, automotive companies are forced to the green challenge, implementing and developing green innovations even if it needs a great effort and a change in their existing technologies and business models.

Previous studies that focused the attention on environmental efforts in this industry generally analyzed the greening of supply chain, manufacturing activities and operation, management of disposal and waste.

Building on previous studies and earlier exploratory research, we identify the green innovations developed by select companies that fall into the four quadrants of Pisano's innovation strategy matrix as our unit of analysis. For each case we analyze in detail the development process. In line with the case study approach [32], data were collected from a variety of sources, including annual reports, corporate websites, and archives of articles from business magazines.

\section{Green Innovations in Automotive Industry}

\subsection{BMW Vehicles in Compliance with USA Emission Standard}

BMW is a German vehicle and engine manufacturing company, a leader in the luxury segment, founded in 1916.

Like other car manufacturers operating in USA market, the company must comply with very different safety, fuel economy, and emissions standards as defined by the federal government.

All automobile manufacturers are exploring ways to reduce the $\mathrm{CO}_{2}$ emissions of their vehicles and increase fuel efficiency, motivated by higher oil prices, increasing concerns of energy security and stringent government regulations.

In the USA, despite the state of California remaining a major force in shaping national legislation and regulations, at the federal level the government manages vehicle emissions controls. In particular, the USA Environmental Protection Agency (EPA) authority defines vehicle and engine emission standards—and air quality in general—based on the Clean Air Act Emission.

In addition, the Clean Air Act establishes a compliance program to implement and enforce the mobile source emission control program.

Over the years, the EPA has adopted standards that cover several mobile sources and implemented the full set of tools provided by congress to guarantee that automobiles meet standards-most notably certification, assembly-line testing, recall, and warranty.

New regulations on fuel and carbon efficiency provided in the recently finalized model year 2017 to 2025 are going to give a huge boost to innovative technologies. These so-called "off-cycle credits" requirements are added to the federal clean car programs standards that require the equivalent of $54.5 \mathrm{mpg}$ by 2025. BMW applied for off-cycle credits for the following technologies: high efficiency exterior lighting, solar reflective glass/glazing, active seat ventilation, active cabin ventilation, and active engine warm-up.

The stop-start ignition systems are considered the big winner of the new credit system. The technology, already popular in Europe, shut off the vehicle when it is not needed, such as when idling at traffic lights. The system allows the reduction of fuel consumption and $\mathrm{CO}_{2}$ emissions 
and it's considered an inexpensive addition to improve environmental performance of conventional gasoline-powered cars.

Successfully meeting the strict exhaust emissions requirements of the North American automobile market, BMW received 3,558,682 credit balances at the end of the 2015 model year, reporting compliance with the standards for the 2012-2015 model years.

All the green innovations related to emission standard compliance make leverage on the existing business model and technical capabilities, thus they can be considered as routine green innovations.

Since they are basically related with existing car technology, these innovations are encompassed into current R\&D department activities or into existing supply chain relationships.

\subsection{Renault Electric Vehicles}

Renault SA is a French company primarily engaged in the manufacture of automobiles and the provision of related services. One of the ways to improve the company's environmental commitment is the continuous development of eco-friendly innovations, such as electric cars.

The introduction of electric cars into company's innovation portfolio represents a radical green innovation, since Renault leverages on existing business models requiring a new set of technical capabilities.

In order to reach these green capabilities, the company invested in R\&D activities and began several partnership and collaboration projects with other players.

Renault spurred creativity internally with the Renault creative people community that allows all Renault Group staff-wherever they are in the world—to put forward new ideas, work through them and have an active role in their implementation. Among the over 10 calls for ideas launched by Renault Creative People, some of them were devoted to projects related to vehicles, $\mathrm{CO}_{2}$ /environment and universal design.

Moreover, the company directed to external sources of knowledge to develop their technical competence for electric cars development.

The alliance with Nissan started in 1999 and had the long-term perspective of changing themselves-the process of working with the unfamiliar adds value, independent of the final outcome.

Among the other rationales of the alliance, Renault is supposed to benefit from the positioning of Nissan in hybrid vehicle technology and in the technologies related to intelligent transportation systems, even if Nissan is far from achieving a leadership position, lagging far behind Toyota and Honda.

The alliance invested around US $\$ 5.2$ billion into the development of electric vehicles and battery programs in order to become the leader in zero-emission transportation.

Besides this knowledge partner, the company had to build a new supply chain relationship. In 2008, the company announced a memorandum of understanding with Better Place-a mobility operator that aims at reducing oil dependence by delivering personal transportation as a sustainable service - to build the world's first Electric Recharge Grid Operator (ERGO) model for Israel. According to the agreement, Renault-Nissan would provide the electric vehicles and the Israeli company would build the electric recharge grid.

The aim of the partnership was to provide complementary assets (electric grid) to stimulate the diffusion of electric cars. Unfortunately, the car's low performance and relatively high price compared with conventional vehicles proved too big a hurdle to overcome, as Better Place failed to attract enough customers.

With the same aim of developing the electrical grid for recharge electric cars, the company also signed partnership agreements with local electricity companies, such as A2A for a pilot project in 2011 "E-MOVING" in Milan and Brescia, and Compagnie Nationale du Rhone (CNR)—an electricity generation company, mainly supplying renewable power from hydroelectric facilities owned by GDF SUEZ, a French multinational electric utility company. 


\subsection{Daimler Car-Sharing Service}

Daimler AG is a German multinational and diversified automotive corporation. It is the thirteenth-largest car manufacturer and second-largest truck manufacturer in the world.

Through Car2go, one of its subsidiaries, the company launched carsharing services in Europe and North American cities. Car2go offers flexible mobility with Smart for Two vehicles, everywhere and at any time for a cheap price in the main city areas of several cities. The Smart can be located and booked via smartphone app or the internet portal and users pay only for the rental time-calculated at intervals of one minute-since other costs, such as parking fees, fuel, taxes and insurance are already included.

In order to change its primary business model, Daimler leveraged on existing technical competences. Thus, the Daimler carsharing system represents a disruptive green innovation.

Despite Daimler being the major shareholder of the company, $25 \%$ of the ownership is held by Europcar. The joint venture with the French car rental company is to share knowledge and capabilities to deploy the new business model. In particular the JV had several advantages for both companies: Europcar's core business is related to fleet management and logistics to offer individual mobility solutions and has always looked forward to mobility behavior at an early stage. The partnership offers customers an extensive network of branches giving further places to register and several mobility options for different occasions. Moreover, the JV is consistent with the aim to serve current and future needs of customers, ensuring innovation of urban mobility.

Indeed, Europcar is already engaged in an Open Innovation program-the Europcar Lab-in order to find new business model to improve the new concept of urban mobility.

In the search of these new mobility solutions, Car2go established several joint or partnership with local governments in order to achieve faster business licensing and approval, exclusive and sufficient operation plates, free parking lots, tax reduction and monetary incentives due to emissions and traffic congestion reduction. Moreover, governments offer platforms for marketing and promotion, and city employees and officials using the car sharing can act as testimonials of the service.

The company also created partnerships in order to enrich the new urban mobility approach. For instance, the company established in 2012 (and completed with the full acquisition in 2014) a strategic partnership with Intelligent Apps, a German market leader into taxi management by smartphones. The rational above the collaboration encompasses several areas of joint product development and marketing initiatives with the aim to achieve added value for customers and greater market penetration. The purpose was for customers to be able to find and book both taxis or Car2go cars. It is also envisaged the development of a common payment system.

Daimler also developed Moovel, the free app available for Android and iOS that combines offers from various mobility service providers and offers the ability to comfortably compare different transportation options with one another regarding travel time and cost. With one single account, users handle booking and payment for several services, such as Car2go, Flinkster, Mytaxi and Deutsche Bahn.

The Daimler subsidiary Moovel has itself leveraged on services from other companies, such as IBM, in order to improve cloud infrastructure.

Among the others in Italy Car2go signed a partnership with Tern, the urban transport specialist that produces high-tech bikes that can be stored into Smarts' luggage compartments and Italo, the Italian railway transportation company, that allows users to cross from one system to another, so that Italo is a catchment area for Car2go and vice versa.

\subsection{Tesla Vehicle Charging System}

Tesla Motors is an American automaker company founded in 2003 in California that produces electric cars and its facilities, such as lithium-ion battery energy storage, and residential solar panels through its SolarCity subsidiary.

Through their innovation and technology, the company has built some of the better electric vehicles ever to be on the market, such as the Roadster, reaching a new niche in the transportation 
market maintaining a significant lead against competitors, and setting new records in terms of quality and performance.

The company has demonstrated the understanding that electric car consumers want ubiquitous fast-charging stations. For this reason, Tesla has built its own Supercharger network of electric filling stations that can bestow enough charge for 170 miles of range in $30 \mathrm{~min}$ or less. In the USA the Superchargers take energy through a solar panel provided by the Elon Musk's company SolarCity.

The Supercharger represents an architectural green innovation, since it requires new technical competences and opens to the company to the opportunity to enter into new business.

In the USA, Tesla awarded Black \& Veatch-an engineering, consulting, construction, and operations company-a contract to design, construct pilot sites and provide energy storage to the Supercharger network, the largest contiguous electric vehicle charging system in the world.

Black \& Veatch is also helping Tesla design battery systems that could serve utility-sized customers.

As part of network improvement, the company is looking for partners such as Sheetz, a mid-Atlantic chain of gas stations, to join its Supercharger station.

In 2014, Tesla signed different agreements with several brands in order to launch the "Destination Charging Location" network by equipping chargers to high-end hotels (i.e., Best Western hotels), restaurants, shopping centers, resorts and other full service stations.

For instance, at the Harrods charging point, inside the popular upmarket department store in London, the company also offers test drives. In 2016 the company found a new partner with the aim ofopening road for its electric car: Airbnb and Tesla are bringing charging stations to select homes across the globe, starting with the California coast.

The company has been always open to collaboration. Indeed, beside Tesla's R\&D lab that is continually engaged in battery and recharging technology, the company has continually collaborated with other partners, such as Daimler and Toyota as original equipment manufacturers (OEMs), Panasonic as an R\&D partner for electric car batteries, or the American technology company NVIDIA as on-board "supercomputer" developer.

\section{Discussion}

Narrative case studies highlight that green innovations are the results of the combination of internal and external sources of knowledge. In particular, taking up the "Green Innovation Landscape Map" and applying it to business cases analyzed it is possible to identify how the presented green innovations in automotive industry are developed (Figure 2).

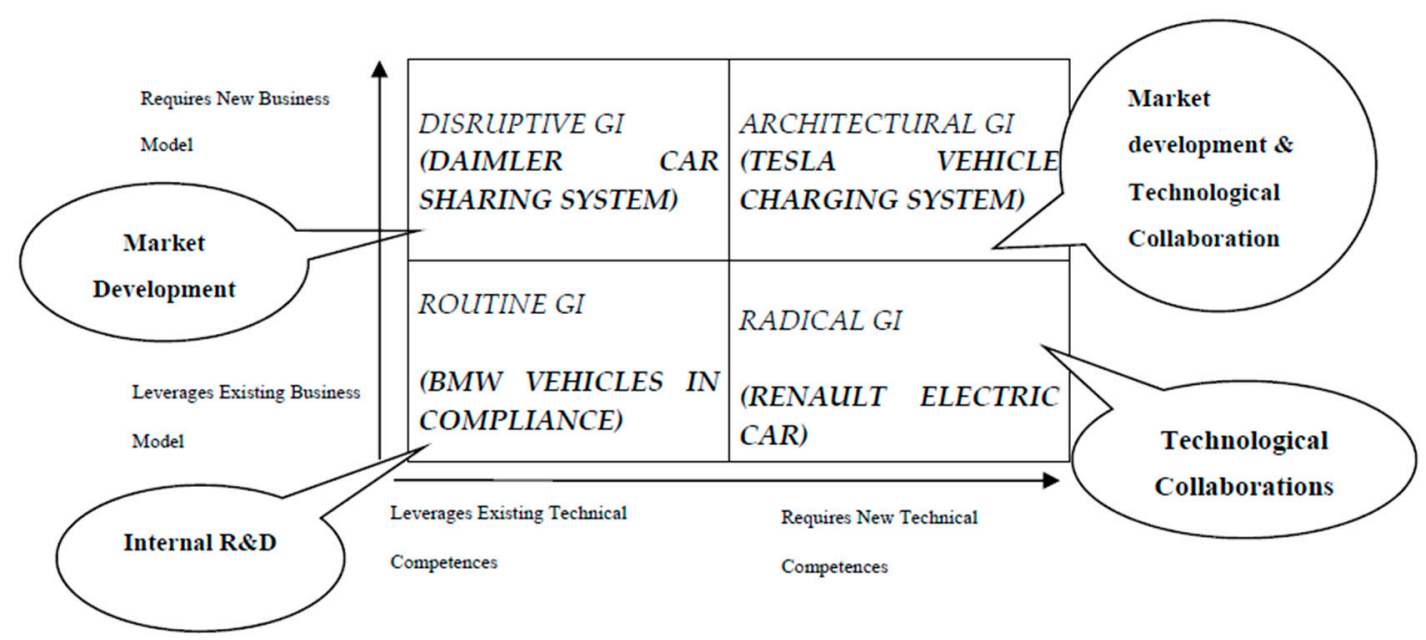

Figure 2. Example of green innovations in the automotive industry. Source: Our elaboration. 
The case of BMW that employs software innovations to produce vehicle in compliance with USA emission standards falls into the first quadrant, where the innovation is conceived into existing business model and leveraging on existing competences.

The company uses the internal R\&D department or existing knowledge or supply chain partners to develop the environmental innovations. This innovation strategy demonstrates the role of government in prompting companies to consider environmental issues, but in this case it does not push BMW to adopt a very green behavior. As highlighted by Pisano [13] according to the mainstream, routine innovation is denigrated as myopic at best and suicidal at worst, while radical, disruptive, and architectural innovations are considered essential to companies' growth.

With regard to green innovations, routine green innovations are rather related to company's "pollution prevention" approach to environment [38] according to which firms continually adapt their products and production processes in order to reduce pollution levels below legal requirements. This behavior toward environmental problem may be viewed as a cost leadership approach, because it is related to the prevention at the source.

It can allow firms to achieve regulatory compliance at a lower cost and to reduce liabilities and only limited resources are committed to manage environmental issues.

Car2Go, developed by Daimler, is rather positioned in quadrant two, as the car sharing system represents a new business model for the company, leveraging on existing technical competences. The case analysis emphasizes that the initiative's success is primarily due to the several collaborations implemented by the company. At first of all, the fruitful equity joint-venture with Europcar allows the company to access to important competences, such as the knowledge of car rental market. Moreover, the company signed several agreements with local government to promote its service, or other companies of the transportation industry (such as bike producers or rail transportation firms) to improve intermodality and sustainable mobility.

The case study shows that when a company implements green innovation by changing its current business model, it needs to start partnership and collaboration with several players to develop the new market for its products or services.

Indeed, in the case of disruptive green innovations the company needs market capabilities that can reach by collaborating with companies that operate in the same business or provide complementary services.

The innovation process of developing the electric car by Renault can be considered a radical green innovation (quadrant III) since the company, while operating with the same business model, introduced a new product leveraging on new technical capabilities.

Also in this case, the company has many relationships with both supply chain and knowledge partners. Renault developed several R\&D alliances with research centers, technology suppliers, governments, and even competitors in the development of its green technologies and in setting technology standards for current and future sustainable mobility.

In this case, considering that the technology acts as a novelty for the effective implementation of green innovation, the company needs to find a technological partner in order to reach the required technical competencies.

Lastly, the case of Tesla vehicle charging system represents an architectural green innovation (quadrant IV). Coherently with company's attitude to technology collaboration, Tesla runs several partnerships to develop and deploy its charging grid. The aim is to allow the creation of network externalities that will also help its electric cars' sales.

Thus, considering that companies that implement architectural green innovation are playing outside their current technological and market domains, both market development and technological collaborations are implemented to enlarge existing knowledge and capabilities.

From the data analysis, it can be seen that companies operating in a non-green industry (e.g., in the automotive sector) that implemented green innovations requiring new technical competences or a new business model turn to other players to a certain extent. 
To develop the disruptive, radical and architectural green innovations, the selected companies implemented an open innovation approach. The companies make extensive use of inter-organizational relationships to in-source external ideas from a variety of innovation sources using a range of external market channels and market internal ideas that fall outside their current business models or technical capabilities. These results are coherent with what many studies on green innovation have affirmed.

The complex nature of green innovation in most cases has made the green shift a multi-party task, requiring the participation of more than an individual firm. Evidence has been found in the recent research emphasizing the growing role of cooperative arrangements in advancing environmental innovations $[22,24,39-41]$.

Azzone and Noci [42] suggest that the effectiveness of environmental programs greatly depends on the executives' capacity to manage environmental innovations jointly with the other competitive factors (time, quality, flexibility, cost, etc.) and to develop new relationships with other firms aimed, for instance, at solving environmental problems that cannot be managed by a single firm, because of the lack in competencies.

Also, De Marchi [22] demonstrates that an important difference among general innovation and green innovation is that $R \& D$ cooperation is more intense than for other innovators. Through statistical analysis conducted in Spanish firms, the study supports theories asserting that environmental innovation implies higher interdependencies with external partners because of their systemic, credence and complex features [43,44].

Other studies demonstrate that green innovations are more cooperation-intensive than general innovations $[10,22,41,45,46]$.

According to Yarahmadi [41], firms may form green partnerships to obtain legitimacy from stakeholders and comply with environmental laws and regulations, or it can represent an opportunity to join evolving market for green innovations. Their motivations to enter into cooperative arrangements are access to new knowledge, sharing risk and pooling resources, each of which is essential to the gaining of competitive advantage.

Thus, using the perspective of resource-based theory, authors suggest that partnerships may help them access diverse resources and capabilities not existing within a single firm [41].

Belin et al. [45] claim that companies that implement green innovations need more external sources of knowledge/information because they are often distinguished by relatively new technologies that can fall outside from company's core business. In addition, Cainelli et al. [47], suggest the essential role of networking and cooperation with universities in order to achieve more radical and relatively new innovations, such as green innovations.

Additionally, Del Rio et al. [48] demonstrate that environmental innovations occurs because of cooperation and information flows since environmental innovators must leverage the competences of external partners to a greater extent than other innovators. Networking with other firms and institutions is important for not just for green innovation development but also for their effective adoption [24].

Only recently, Ghisetti et al. [49] highlighted the need to focus on the interaction between the firm and its external environment. In doing so, they shed light on a little known phenomenon, namely, the open eco-innovation mode (OEIM). They demonstrate that both the breadth and the depth of the firm's knowledge sourcing, considered respectively as the set of sources upon which it draws in order to access external knowledge and the extent to which firms draw intensively on external knowledge providers [50], have a positive effect on green innovation.

Faceux and Nicolai [51] claim for the adoption of IT to create of collective "platforms" for the collaboration of heterogeneous stakeholders in order to generate eco-innovation.

Although authors already focus on the importance of external knowledge in the development of green innovations, to the best of our knowledge none of them have stressed the dynamics of green technology development considering the kinds of green innovation implemented. Moreover, this 
specific peculiarity of green innovation has been acknowledged only recently [47] and has not always been confirmed by empirical evidence [52].

Our results demonstrate why alliances are so frequent in green innovations: specific kinds of green innovations imply an important change in a company's existing business and technical competences, consequently they force the companies to acquire these competences working with other companies.

Nevertheless, it is important to note that the development of disruptive, radical and architectural green innovations requires not just spot relations between partners, where individuals exchange relevant information and resources in support of each other's goals, but a strong collaboration among partners that create something new with a shared vision.

Through business collaboration, companies can enhance innovation thanks to the amount and variety of knowledge that can shared, especially for green innovations, where the projects have longer-term results and resources are pooled or jointly secured for a long-term effort.

\section{Conclusions}

The implementation of green innovations represents an important challenge for non-green companies because it often requires the acquisition of new resources and competences that differ significantly from the competences already owned.

Previous studies on green innovations often neglect this latter aspect, because they have generally been focused on defining the specific features that distinguish green innovations from generic ones, on the effect of environmental policies, on fostering these innovation activities, on the drivers of green innovations, and its effect on firms' competitiveness. Extant contributions fail to focus on "how" the process necessary to develop green innovations occurs.

This paper aims to shed light on this field by focusing on four different green innovations developed by energy companies—categorized using the Pisano [13] landscape map-in order to identify different sources of innovation advancement.

From case study analysis, it can be seen that when a company operating in a non-green industry implements a green innovation that requires new technical competences or a new business model it turns to other players to a certain extent.

To develop the disruptive, radical and architectural green innovations the selected companies turn to collaboration with market or technological partners, in order to in-source external ideas from a variety of innovation sources due to the fact that these innovations fall outside their current business model or technical capabilities. The implementation of such innovations requires a strong collaboration among partners that create something new with a shared vision. The need to improve a company's environmental performance is seen as a major source of change [42], leading to significant modifications of the corporate relationships with external stakeholders, such as other companies. They can enhance collaboration with external partners to improve their green technological change.

As a practical implication, the case studies suggest that even for big companies with internal R\&D departments, collaboration with other players is a viable way to improve innovation performance, especially in eco-friendly fields. On the contrary, the collaboration also helps SME with limited financial and knowledge resources to access new competences and capabilities useful to change the technology, the business model or both, and develop green innovations more easily and with lower costs.

Tesla, for instance, is a small company with a limited manufacturing capability, especially if compared to bigger companies.

From the study it emerges that managers and executives should be encouraged to invest in the creation/strengthening of external and internal networks, through which relevant environmental knowledge can be exchanged. Indeed, these relationships may allow firms to access heterogeneous technological competencies, whose integration provides the complexity characterizing green innovations development process [25].

Policymakers can also find interesting suggestions from this case study. Environmental regulation is not an exclusive way to promote firms' environmental engagement. In contrast, standards and 
regulatory pressure often push companies to adopt compliance behavior rather than pushing them towards a more complex and proactive solution to environmental problems.

The rise of new and innovative business models in non-green industries demonstrates that environmentalism is not only a management trend or a green washing marketing issue but also an alternative way to create value and build or maintain competitive advantage.

Regulators should set policies that not only support firms' internal eco-innovative efforts but also their interactions with external actors and knowledge sources, since in the environmental context, internal and external knowledge is more complementary than in other contexts

In addition, this paper offers valuable academic implications. From the theoretical standpoint, it underlines the necessity to study in depth how green innovations are conceived and realized, since these innovations often occur when different players (firms, universities, governments, etc.) collaborate, join efforts and share risks. The openness of to develop these innovations can be considered an important feature in spurring green technological change. Thus, this research can represent a starting point for deep consideration about the relationship between green innovation typology and mode of development.

Our research has some limitations, mainly linked to the descriptive nature of the study since results cannot be generally applicable or generalizable. In the same time, our study raises some directions for future research.

First, this study focuses on the automotive industry, so further research can focus on other non-green industries or make a comparison between the green innovation process of firms operating in green and non-green industries. Secondly, it could be interesting to evaluate the company's performance of the different green innovations in order to evaluate the specific typology and mode of development that allow better economic and financial performance.

Author Contributions: Adele Parmentola, Ilaria Tutore and Francesco Calza conceived and designed the research; Adele Parmentola and Ilaria Tutore analyzed the data; Francesco Calza, Adele Parmentola and Ilaria Tutore wrote the paper.

Conflicts of Interest: The authors declare no conflict of interest.

\section{References}

1. Wood, D.J.; Jones, R.E. Stakeholder mismatching: A theoretical problem in empirical research on corporate social performance. Int. J. Organ. Anal. 1995, 3, 229-267. [CrossRef]

2. Hart, S.L.; Ahuja, G. Does it pay to be green? Bus. Strategy Environ. 1996, 5, 31-37. [CrossRef]

3. Chen, Y.S.; Lai, S.B.; Wen, C.T. The influence of green innovation performance on corporate advantage in Taiwan. J. Bus. Ethics 2006, 67, 331-339. [CrossRef]

4. Oltra, V.; Saint Jean, M. Sectoral systems of environmental innovation: An application to the French automotive industry. Technol. Forecast. Soc. Chang. 2009, 76, 567-583. [CrossRef]

5. Orsato, R.J. Competitive Environmental Strategies: When Does It Pay to Be Green? Calif. Manag. Rev. 2006, 48, 127-143. [CrossRef]

6. Porter, M.E.; Van Der Linde, C. Toward A New Conception of the Environment-Competitiveness Relationship. J. Econ. Perspect. 1995, 9, 97-118. [CrossRef]

7. Schiederig, T.; Tietze, F.; Herstatt, C. Green innovation in technology and innovation management-An exploratory literature review. Res. Dev. Manag. 2012, 42, 180-192. [CrossRef]

8. Cainelli, G.; Mazzanti, M.; Zoboli, R. Environmental innovations, complementarity and local/global cooperation: Evidence from North-East Italian industry. Int. J. Technol. Policy Manag. 2011, 11, 328-368. [CrossRef]

9. Gonzales-Benito, J.C.; Gonzales-Benito, O.C. A Review of Determinant Factors of Environmental Proactivity. Bus. Strategy Environ. 2006, 15, 87-102. [CrossRef]

10. Horbach, J.; Oltra, V.; Belin, J. Determinants and Specificities of Eco-Innovations Compared to Other Innovations-An Econometric Analysis for the French and German Industry Based on the Community Innovation Survey. Ind. Innov. 2013, 20, 523-543. [CrossRef] 
11. Kesidou, E.; Demirel, P. On the drivers of eco-innovations: Empirical evidence from the UK. Res. Policy 2012, 41, 862-870. [CrossRef]

12. Rennings, K. Redefining Innovation-Eco-Innovation Research and the Contribution from Ecological Economics. Ecol. Econ. 2000, 32, 319-332. [CrossRef]

13. Pisano, G.P. You Need an Innovation Strategy. Harv. Bus. Rev. 2015, 93, 44-54.

14. Yim, S.H.L.; Fung, J.C.H.; Lau, A.K.H. Use of high-resolution MM5/CALMET/CALPUFF system: $\mathrm{SO}_{2}$ apportionment to air quality in Hong Kong. Atmos. Environ. 2010, 44, 4850-4858. [CrossRef]

15. Kammerer, D. The effects of customer benefit and regulation on environmental product innovation. Empirical evidence from appliance manufacturers in Germany. Ecol. Econ. 2009, 68, 2285-2295. [CrossRef]

16. Kleindorfer, P.R.; Singhal, K.; Wassenhove, L.N. Sustainable operations management. Prod. Oper. Manag. 2005, 14, 482-492. [CrossRef]

17. Lambertini, L.; Mantovani, A. Process and product innovation by a multiproduct monopolist: A dynamic approach. Int. J. Ind. Organ. 2009, 27, 508-518. [CrossRef]

18. Mu, J.; Peng, G.; Maclachlan, D.L. Effect of risk management strategy on NPD performance. Technovation 2009, 29, 170-180. [CrossRef]

19. Fussler, C.; James, P. A Breakthrough Discipline for Innovation and Sustainability; Pitman Publishing: London, UK, 1996.

20. Kemp, R.; Pearson, P. Final Report Mei Project about Measuring Eco-Innovation; Um-Merit: Maastricht, The Netherlands, 2007.

21. Driessen, P.H.; Hillebrand, B. Adoption and diffusion of green innovations. In Marketing for Sustainability: Towards Transactional Policy-Making; IOS Press: Amsterdam, The Netherlands, 2002.

22. De Marchi, V. Environmental Innovation and Randd Cooperation: Empirical Evidence from Spanish Manufacturing Firms. Res. Policy 2012, 41, 614-623. [CrossRef]

23. Jaffe, A.B.; Newell, R.G.; Stavins, R.N. A Tale of Two Market Failures: Technology and Environmental Policy. Ecol. Econ. 2005, 54, 164-174. [CrossRef]

24. Horbach, J. Determinants of Environmental Innovation-New Evidence from German Panel Data Sources. Res. Policy 2008, 37, 163-173. [CrossRef]

25. Petruzzelli, M.A.; Dangelico, M.R.; Rotolo, D.; Albino, V. Organizational factors and technological features in the development of green innovations: Evidence from patent analysis. Innovation 2011, 13, 291-310. [CrossRef]

26. Chen, Y.S. The driver of green innovation and green image-Green core competence. J. Bus. Ethics 2008, 81, 531-543. [CrossRef]

27. Chen, Y.S.; Chang, C.H.; Lin, Y.H. The determinants of green radical and incremental innovation performance: Green shared vision, green absorptive capacity, and green organizational ambidexterity. Sustainability 2014, 6, 7787-7806. [CrossRef]

28. De Burgos-Jiménez, J.; Vázquez-Brust, D.; Plaza-Úbeda, J.A.; Dijkshoorn, J. Environmental protection and financial performance: An empirical analysis in Wales. Int. J. Oper. Prod. Manag. 2013, 33, 981-1018. [CrossRef]

29. Weng, H.H.R.; Chen, J.S.; Chen, P.C. Effects of green innovation on environmental and corporate performance: A stakeholder perspective. Sustainability 2015, 7, 4997-5026. [CrossRef]

30. Chen, Y.; Chang, C.; Wu, F. Origins of green innovations: The differences between proactive and reactive green innovations. Manag. Decis. 2012, 50, 368-398. [CrossRef]

31. Eisenhardt, K.M.; Graebner, M.E. Theory Building from Cases: Opportunities and Challenges. Acad. Manag. J. 2007, 50, 25-32. [CrossRef]

32. Yin, R.K. Discovering the Future of the Case Study Method in Evaluation Research. Eval. Pract. 1994, 15, 283-290. [CrossRef]

33. Eisenhardt, K.M. Building Theories from Case Study Research. Acad. Manag. Rev. 1989, 14, 532-550.

34. Nunes, B.; Bennett, D. Green operations initiatives in the automotive industry: An environmental reports analysis and benchmarking study. Benchmarking Int. J. 2010, 17, 396-420. [CrossRef]

35. Kuik, O.J. Environmental Innovation Dynamics in the Automotive Industry: A Case Study in the Framework of the Project-Assessing Innovation Dynamics Induced by Environment Policy; Working Paper; European Commission: Brussels, Belgium; Lexembourg, 2007. 
36. Bennett, D.J. Eight Steps for Managing Green Innovation in the Automotive Industry. Eur. Financ. Rev. 2013, 13, 3-6.

37. Zailani, S.; Govindan, K.; Iranmanesh, M.; Shaharudin, M.R.; Chong, Y.S. Green innovation adoption in automotive supply chain: The Malaysian case. J. Clean. Prod. 2015, 108, 1115-1122. [CrossRef]

38. Buysse, K.; Verbeke, A. Proactive Environmental Strategies: A Stakeholder Management Perspective. Strateg. Manag. J. 2003, 24, 453-470. [CrossRef]

39. Vachon, S.; Klassen, R.D. Environmental management and manufacturing performance: The role of collaboration in the supply chain. Int. J. Prod. Econ. 2008, 111, 299-315. [CrossRef]

40. Mazzanti, M.; Zoboli, R. Environmental efficiency and labour productivity: Trade-off or joint dynamics? A theoretical investigation and empirical evidence from Italy using NAMEA. Ecol. Econ. 2009, 68, 1182-1194. [CrossRef]

41. Yarahmadi, M.; Higgins, P.G. Motivations towards environmental innovation: A conceptual framework for multiparty cooperation. Eur. J. Innov. Manag. 2012, 15, 400-420. [CrossRef]

42. Azzone, G.; Noci, G. Seeing ecology and "green" innovations as a source of change. J. Organ. Chang. Manag. 1998, 11, 2. [CrossRef]

43. Seuring, S.; Müller, M. From a Literature Review to a Conceptual Framework for Sustainable Supply Chain Management. J. Clean. Prod. 2008, 16, 1699-1710. [CrossRef]

44. Theyel, G. Customer and Supplier Relations for Environmental Performance. In Greening the Supply Chain; Springer: London, UK, 2006; pp. 139-149.

45. Belin, J.; Horbach, J.; Oltra, V. Determinants and Specificities of Eco-Innovations-An Econometric Analysis for The French and German Industry Based on the Community Innovation Survey; No. 2011-17; Groupe De Recherche en Economie Théorique et Appliquée: Bordeaux, France, 2011.

46. Rennings, K.; Rammer, C. Increasing Energy and Resource Efficiency Through Innovation-An Explorative Analysis Using Innovation Survey Data. In ZEW-Centre for European Economic Research Discussion; No. 09-056; ZEW: Mannheim, Germany, 2009.

47. Cainelli, G.; Mazzanti, M.; Montresor, S. Environmental Innovations, Local Networks and Internationalization. Ind. Innov. 2012, 19, 697-734. [CrossRef]

48. Del Río, P.; Peñasco, C.; Romero-Jordán, D. Distinctive Features of Environmental Innovators: An Econometric Analysis. Bus. Strategy Environ. 2015, 24, 361-385. [CrossRef]

49. Ghisetti, C.; Marzucchi, A.; Montresor, S. The Open Eco-Innovation Mode. An Empirical Investigation of Eleven European Countries. Res. Policy 2015, 44, 1080-1093. [CrossRef]

50. Laursen, K.; Salter, A. Open for Innovation: The Role of Openness in Explaining Innovation Performance among UK Manufacturing Firms. Strateg. Manag. J. 2006, 27, 131-150. [CrossRef]

51. Faucheux, S.; Nicolaï, I. IT for green and green IT: A proposed typology of eco-innovation. Ecol. Econ. 2011, 70, 2020-2027. [CrossRef]

52. Bönte, W.; Dienes, C. Environmental Innovations and Strategies for the Development of New Production Technologies: Empirical Evidence from Europe. Bus. Strategy Environ. 2013, 22, 501-516. [CrossRef]

(C) 2017 by the authors. Licensee MDPI, Basel, Switzerland. This article is an open access article distributed under the terms and conditions of the Creative Commons Attribution (CC BY) license (http:/ / creativecommons.org/licenses/by/4.0/). 